\title{
PENGARUH BOKASHI SEKAM PADI TERHADAP HASIL TANAMAN JAGUNG MANIS (Zea mays, L Sacharata) PADA TANAH ULTISOL
}

\author{
Nurhadiah \\ Fakultas Pertanian Universitas Kapuas Sintang \\ Email: diah.nurhadiah@yahoo.co.id
}

\begin{abstract}
Abstrak: Bokashi sekam padi dapat diaplikasikan pada tanah podsolik merah kuning, dan dapat memperbaiki sifat fisik, kimia dan biologi tanah. Penelitian ini bertujuan untuk mengetahui pengaruh pemberian bokashi sekam padi terhadap hasil tanaman jagung manis pada tanah PMK, dan mengetahui dosis bokashi yang tepat untuk mendapatkan hasil tanaman jagung manis tertinggi pada tanah PMK. Penelitian dilakukan dengan Rancangan Acak Kelompok (RAK), dengan satu perlakuan. Perlakuan yang digunakan adalah bokashi sekam padi yang terdiri dari 6 (enam) taraf perlakuan: tanpa bokashi sekam padi / kontrol ( $\left.\mathrm{b}_{0}\right), 0,5 \mathrm{~kg}$ bokashi sekam padi $\left(\mathrm{b}_{1}\right) / \mathrm{m}^{2}, 1 \mathrm{~kg}$ bokashi sekam padi $\left(\mathrm{b}_{2}\right) / \mathrm{m}^{2}, 1,5 \mathrm{~kg}$ bokashi sekam padi $\left(\mathrm{b}_{3}\right) / \mathrm{m}^{2}, 2 \mathrm{~kg}$ bokashi sekam padi $\left(\mathrm{b}_{4}\right) / \mathrm{m}^{2}, 2,5 \mathrm{~kg}$ bokashi sekam padi $\left(\mathrm{b}_{5}\right) / \mathrm{m}^{2}$. Peubah yang diamati yaitu berat tongkol kotor, berat tongkol kupasan dan persentase panjang tongkol kosong dengan panjang tongkol isi. Data hasil penelitian dianalisis dengan analisis sidik ragam dan uji BNJ. Hasil penelitian diketahui bahwa bokashi sekam padi berpengaruh terhadap hasil tanaman jagung manis pada tanah PMK. Pemberian bokashi sekam padi sebanyak $2,5 \mathrm{~kg}$ per $\mathrm{m}^{2}$ atau setara dengan 25 ton per hektar memberikan hasil jagung manis tertinggi pada tanah PMK yang ditandai dengan rerata berat tongkol kotor 201 gram per tanaman, rerata berat tongkol kupasan 184,25 gram, dan persentase panjang tongkol kosong terhadap tongkol isi $25,21 \%$.
\end{abstract}

Kata kunci: bokashi sekam padi, tanah PMK, jagung, hasil.

\section{PENDAHULUAN}

Jagung merupakan bahan

makanan pokok setelah beras dan sekitar 90\% dari produksi jagung di Indonesia digunakan untuk konsumsi. Selain itu juga dapat digunakan untuk makanan ternak (Rukmana, 2013:2). Produksi jagung Kalimantan Barat tahun 2014 sebesar 135.183 ton, mengalami penurunan sebesar 15,50 persen jika dibandingkan dengan angka tetap tahun 2013 yang sebesar 159.973 ton.
Penurunan produksi disebabkan oleh menurunnya luas panen sebsar 13,83 persen dan penurunan produktivitas sebesar 1,92 persen (BPS, 2015).

Penurunan produktivitas diantaranya dapat disebabkan oleh jenis tanah yang kurang mendukung serta sistem budidaya yang kurang maksimal. Dalam budidaya tanaman, yang umum dilakukan adalah penggunaan bahan kimia dalam berbagai kegiatan pertanian, baik untuk pemupukan, 
pemacu pertumbuhan serta pengendalian hama, penyakit dan gulma. Penggunakaan bahan kimia ini berdampak terhadap keberlanjutan lahan dalam mendukung pertumbuhan dan hasil tanaman pada lahan tersebut, serta dapat merusak lingkungan dan kesehatan manusia. Menurut Taufik (2004:2), solusi yang terbaik adalah menanam dengan sistem pertanian organik yaitu menanam dengan menggunakan bahanbahan organik yang aman bagi lingkungan.

Bahan organik yang dapat digunakan diantaranya sekam padi yang tidak dimanfaatkan setelah proses penggilingan padi. Sekam padi dijadikan bokashi, sehingga dapat dengan cepat terdekomposisi. Pemberian bokashi dapat diaplikasikan pada tanah podsolik merah kuning, dan dapat memperbaiki sifat fisik, kimia dan biologi tanah. Menurut Yusuf (2000:2), bokashi mempunyai kandungan unsur hara mikro yang sangat lengkap walaupun jumlahnya yang sangat sedikit. Selain itu bahwa bokashi mempunyai kelebihan lain yaitu semakin memperbanyak dan beragamnya bakteri positif tanah yang ada pada lahan pertanian, dimana bakteri tersebut sebagian adalah bakteri penambat $\mathrm{N}, \mathrm{P}$ dan $\mathrm{K}$ sehingga secara tidak langsung bakteri-bakteri tersebut akan menyediakan unsur hara bagi tanaman itu sendiri, dan kelebihan lain yang didapat dari bokashi dan pupuk organik lain yaitu kemampuannya untuk memperbaiki struktur tanah.

Bokashi merupakan bahan organik yang sangat dibutuhkan oleh tanah atau mikroba dalam tanah untuk memperbaiki struktur tanah dan menjaga dinamika daya dukung lahan (Dinas Pertanian Kabupaten Jombang, 2010). Pemberian bokashi pada tanah podsolik merah kuning diharapkan dapat meningkatkan $\mathrm{p}$ hasil jagung pada tanah podsolik merah kuning terutama di kabupaten Sintang

\section{METODOLOGI PENELITIAN}

Penelitian dilaksanakan di Kecamatan Kelam Permai Kabupaten Sintang. Penelitian dimulai bulan April sampai Juli 2016, dengan rancangan percobaan yang digunakan adalah Rancangan Acak Kelompok (RAK). Perlakuan yang digunakan yaitu bokashi sekam padi yang terdiri dari 6 (enam) taraf perlakuan: tanpa bokashi sekam padi / kontrol ( $\left.\mathrm{b}_{0}\right), 0,5 \mathrm{~kg}$ bokashi sekam padi $\left(b_{1}\right) / \mathrm{m}^{2}, 1 \mathrm{~kg}$ bokashi sekam padi $\left(b_{2}\right) / \mathrm{m}^{2}, 1,5 \mathrm{~kg}$ bokashi sekam padi $\left(\mathrm{b}_{3}\right)$ $/ \mathrm{m}^{2}, 2 \mathrm{~kg}$ bokashi sekam padi $\left(\mathrm{b}_{4}\right) / \mathrm{m}^{2}$, 
2,5 $\mathrm{kg}$ bokashi sekam padi $\left(\mathrm{b}_{5}\right) / \mathrm{m}^{2}$. Jumlah tanaman dalam satu taraf perlakuan 8 tanaman yang diulang 5 kali, sehingga jumlah populasi dalam penelitian ini sebanyak 240 tanaman, dengan jumlah sampel sebanyak 120 tanaman (6 taraf perlakuan x 5 ulangan $\mathrm{x}$ 4 tanaman).

Bahan-bahan yang digunakan yaitu: bokashi sekam padi, benih jagung, kotoran ayam, furadan, decis dan dithane M-45, sedangakan alat yang dipergunakan terdiri dari: cangkul, parang, gembor, timbangan, meteran pita, jangka sorong, kamera dan alat tulis. Peubah yang diamati yaitu berat tongkol kotor, berat tongkol kupasan dan persentase panjang tongkol kosong dengan panjang tongkol isi.

Data yang diperoleh dianalisis statistik dengan menggunakan rancangan acak kelompok, dan kemudian jika perlakuan memberikan pengaruh terhadap hasil, maka dilanjutkan dengan uji Beda Nyata Jujur $(\mathrm{BNJ})$.

\section{HASIL DAN PEMBAHASAN}

\section{Hasil penelitian}

\section{Berat Tongkol Kotor}

Berat tongkol kotor diperoleh dengan menimbang tongkol jagung sebelum dikupas kulitnya. Data berat tongkol kotor, dianalisis statistik yang disajikan pada Tabel 1.

Tabel 1. Anlisis ragam pengaruh bokashi sekam padi terhadap berat tongkol kotor

\begin{tabular}{|c|c|c|c|c|c|c|}
\hline \multirow{2}{*}{ SK } & \multirow{2}{*}{ DB } & \multirow{2}{*}{ JK } & \multirow{2}{*}{ KT } & \multirow{2}{*}{ F Hit. } & \multicolumn{2}{|c|}{ F Tab. } \\
\hline & & & & & 0,05 & 0,01 \\
\hline Ulangan & 4 & 1615,63 & 403,91 & $2,84^{\text {tn }}$ & 2,87 & 4,43 \\
\hline Perlakuan & 5 & 23881,09 & 4776,22 & $33,52^{* *}$ & 2,71 & 4,10 \\
\hline Galat & 20 & 2849,38 & 142,47 & & & \\
\hline Total & 29 & 28346,09 & & $\mathrm{kk}=7,05$ & & \\
\hline
\end{tabular}

Pemberian bokashi berpengaruh sangat nyata terhadap berat tongkol kotor per tanaman, seperti yang terlihat dalam Tabel 1, sehingga untuk mengetahui taraf perlakuan mana yang memberikan rerata berat tongkol kotor teringgi, maka dilanjutkan dengan uji BNJ, disajikan pada Tabel 2.

Tabel 2. Uji BNJ bokashi sekam padi terhadap berat tongkol kotor (g) 


\begin{tabular}{ccccccc}
\hline \hline Perlakuan & Rerata & \multicolumn{5}{c}{ Beda } \\
\hline $\mathrm{b}_{0}$ & $112,00 \mathrm{a}$ & - & & & & \\
$\mathrm{b}_{1}$ & $162,25 \mathrm{~b}$ & $50,25^{* *}$ & - & & & \\
$\mathrm{b}_{2}$ & $173,50 \mathrm{c}$ & $61,50^{* *}$ & $11,25^{*}$ & - & & \\
$\mathrm{b}_{3}$ & $182,50 \mathrm{c}$ & $70,50 \mathrm{~b}^{* *}$ & $20,25^{* *}$ & $9,00^{\text {tn }}$ & - & \\
$\mathrm{b}_{4}$ & $185,00 \mathrm{~d}$ & $73,00 \mathrm{~b}^{* *}$ & $22,75^{* *}$ & $11,50^{* *}$ & $2,50^{\text {tn }}$ & - \\
$\mathrm{b}_{5}$ & $201,00 \mathrm{e}$ & $89,00 \mathrm{~b}^{* *}$ & $38,75^{* *}$ & $27,50^{* *}$ & $18,50^{* *}$ & $16,00^{* *}$ \\
\hline
\end{tabular}

BNJ 0.05 = 10,10

Sumber : data pengamatan, 2016

Keterangan : tn = tidak beda nyata pada taraf 0,05

** = beda sangat nyata pada taraf 0,01

Angka ditandai huruf sama menunjukkan tidak beda nyata pada taraf 0,05

Hasil uji BNJ menunjukkan pemberian 2,5 $\mathrm{kg}$ bokashi sekam padi pada tanah PMK menghasilkan tongkol kotor paling berat dari taraf perlakuan lainnya.

\section{Berat Tongkol Kupasan}

Berat tongkol kupasan diperoleh dengan menimbang tongkol yang sudah dibuang kulitnya. Hasil rerata pengamatan dianalisis dengan analisis sidik ragam seperti yang terlihat dalam Tabel 3.

Tabel 3. Analisis ragam pengaruh bokashi sekam padi terhadap berat tongkol kupasan

\begin{tabular}{lccccrc}
\hline \multirow{2}{*}{ SK } & \multirow{2}{*}{ DB } & \multirow{2}{*}{ JK } & KT & F Hit. & $\mathbf{0 , 0 5}$ & $\mathbf{0 , 0 1}$ \\
\hline Ulangan & 4 & 2746,67 & 686,67 & $4,08^{*}$ & 2,87 & 4,43 \\
Perlakuan & 5 & 34264,84 & 6852,97 & $40,74^{* *}$ & 2,71 & 4,10 \\
Galat & 20 & 3364,58 & 168,23 & & & \\
\hline Total & $\mathbf{2 9}$ & $\mathbf{4 0 3 7 6 , 0 9}$ & & kk $=$ & $\mathbf{9 , 0 1 \%}$ & \\
\hline
\end{tabular}

Sumber : data pengamatan, 2016

Keterangan : $*$ pengaruh nyata pada taraf 0,05

$* * \quad=$ pengaruh sangat nyata pada taraf 0,01

Hasil analisis ragam (Tabel 3) menunjukkan bahwa perlakuan bokashi sekam padi memberikan pengaruh yang sangat nyata terhadap berat tongkol kupasan. Untuk mengetahui taraf perlakuan yang memberikan berat tongkol kupasan paling berat, dilakukan uji BNJ seperti pada Tabel 4. 


\begin{tabular}{|c|c|c|c|c|c|c|}
\hline Perlakuan & Rerata & & & Beda & & \\
\hline $\mathrm{b}_{0}$ & $76,00 \mathrm{a}$ & - & & & & \\
\hline$b_{1}$ & $135,50 \mathrm{~b}$ & $59,50^{* *}$ & - & & & \\
\hline $\mathrm{b}_{2}$ & $147,50 \mathrm{c}$ & $71,50^{* *}$ & $12,00^{*}$ & - & & \\
\hline $\mathrm{b}_{3}$ & $157,50 \mathrm{~cd}$ & $81,50^{* *}$ & $22,00^{* *}$ & $10,00^{\operatorname{tn}}$ & - & \\
\hline$b_{4}$ & $162,50 \mathrm{~d}$ & $86,50^{* *}$ & $27,00^{* *}$ & $15,00^{* * *}$ & $5,00^{\operatorname{tn}}$ & - \\
\hline $\mathrm{b}_{5}$ & $184,25 \mathrm{e}$ & $108,25^{* *}$ & $48,75^{* *}$ & $36,75^{* *}$ & $26,75^{* *}$ & $21,75^{\text {** }}$ \\
\hline
\end{tabular}

Sumber : data pengamatan, 2016

Keterangan $:$ tn $\quad=$ tidak beda nyata pada taraf 0,05

** = beda sangat nyata pada taraf 0,01

Angka ditandai huruf sama menunjukkan tidak beda nyata pada taraf 0,05

Hasil uji BNJ seperti yang tersaji dalam Tabel 4 memperlihatkan bahwa pemberian 2,5 $\mathrm{kg}$ bokashi sekam padi pada tanah PMK menghasilkan tongkol kupasan paling berat dari taraf perlakuan yang lain. Sedangkan pada pemberian 2 $\mathrm{kg}$ bokashi pada tanah PMK, tongkol kupasan yang dihasilkan tidak lebih berat daripada pemberian $1,5 \mathrm{~kg}$, dan pemberian $1,5 \mathrm{~kg}$ bokashi menghasilkan tongkol kupasan lebih berat dari pemberian $1 \mathrm{~kg}$.

\section{Persentase panjang tongkol kosong terhadap tongkol isi}

Persentase panjang tongkol kosong terhadap tongkol isi diperoleh dengan mengukur panjang bagian tongkol yang kosong dibagi panjang tongkol keseluruhan dikali seratus. Untuk mengetahui pengaruh pemberian bokashi sekam padi terhadap persentase panjang tongkol kosong terhadap tongkol isi dianalisis dengan analisis statistik yang disajikan pada Tabel 5.

Tabel 5. Analisis sidik ragam pengaruh bokashi sekam padi terhadap persentase panjang tongkol kosong terhadap tongkol isi (\%).

\begin{tabular}{|c|c|c|c|c|c|c|}
\hline \multirow{2}{*}{ SK } & \multirow{2}{*}{ DB } & \multirow{2}{*}{ JK } & \multirow{2}{*}{ KT } & \multirow{2}{*}{ F Hit. } & \multicolumn{2}{|c|}{ F Tab. } \\
\hline & & & & & 0,05 & $\mathbf{0 , 0 1}$ \\
\hline Ulangan & 4 & 952,24 & 238,06 & $15,08^{* *}$ & 2,87 & 4,43 \\
\hline Perlakuan & 5 & 936,85 & 187,37 & $11,87^{* *}$ & 2,71 & 4,10 \\
\hline Galat & 20 & 315,68 & 15,78 & & & \\
\hline Total & 29 & 2204,77 & & $\mathrm{kk}=$ & $12,46 \%$ & \\
\hline
\end{tabular}


Hasil analisis sidik ragam seperti

pada Tabel 5 menunjukkan bahwa

perlakuan bokashi sekam padi

berpengaruh sangat nyata terhadap

persentase panjang tongkol kosong terhadap tongkol isi. Untuk mengetahui taraf perlakuan yang memberikan persentase panjang tongkol kosong terhadap tongkol isi yang terendah, dilakukan uji BNJ seperti pada Tabel 6.

Tabel 6. Uji BNJ bokashi sekam padi terhadap persentase panjang tongkol kosong terhadap tongkol isi (\%).

\begin{tabular}{ccccccc}
\hline Perlakuan & Rerata & \multicolumn{5}{c}{ Beda } \\
\hline $\mathrm{b}_{5}$ & $25,21 \mathrm{a}$ & - & & & & \\
$\mathrm{b}_{4}$ & $28,34 \mathrm{a}$ & $3,13^{\text {tn }}$ & - & & & \\
$\mathrm{b}_{3}$ & $29,83 \mathrm{~b}$ & $4,62^{* *}$ & $1,49^{\text {tn }}$ & - & & \\
$\mathrm{b}_{2}$ & $32,30 \mathrm{~b}$ & $7,09^{* *}$ & $2,46^{\text {tn }}$ & $0,97^{\text {tn }}$ & - & \\
$\mathrm{b}_{1}$ & $32,58 \mathrm{c}$ & $7,37^{* *}$ & $4,24^{* *}$ & $2,75^{\text {tn }}$ & $0,28^{\text {tn }}$ & - \\
$\mathrm{b}_{0}$ & $43,08 \mathrm{~d}$ & $17,87^{* *}$ & $14,74^{* *}$ & $13,25^{* *}$ & $10,78^{* *}$ & $10,50^{* *}$ \\
\hline
\end{tabular}

BNJ 0.05 $=\quad 3,36$

Sumber : data pengamatan, 2016

Keterangan : tn = tidak beda nyata pada taraf 0,05

** = beda sangat nyata pada taraf 0,01

Angka ditandai huruf sama menunjukkan tidak beda nyata pada taraf 0,05

Hasil uji BNJ pada Tabel 6 menunjukkan bahwa persentase panjang tongkol kosong terhadap tongkol isi yang terendah adalah pemberian $2,5 \mathrm{~kg}$ bokashi sekam padi pada tanah PMK. Sedangkan persentase panjang tongkol kosong terhadap tongkol isi yang tertinggi adalah tanah atau lahan yang tidak diberi bokashi.

\section{Pembahasan}

Hasil analisis ragam menunjukkan pemberian bokashi sekam padi berpengaruh sangat nyata terhadap hasil tanaman jagung manis pada tanah PMK. Hal ini terlihat dari hasil penelitian terhadap berat tongkol kotor, berat tongkol kupasan, dan persentase panjang tongkol kosong terhadap tongkol isi. Pengaruh ini diduga disebabkan oleh membaiknya kondisi tanah, baik sifat fisik, kimia dan biologi tanah. Pemberian bokashi sekam padi pada tanah PMK dapat menjadikan tanah gembur, air dapat terserap dengan baik, serta akar dapat tumbuh dengan mudah. Bokashi sekam padi juga dapat menambah ketersediaan hara dalam tanah, dan juga dapat mengaktifkan kerja mikroorganisme tanah dalam mendekomposisikan bahan organik. Menurut Hamzah dkk (2007:1-7), 
ketersediaan hara dalam tanah, struktur tanah dan tata udara tanah yang baik sangat mempengaruhi pertumbuhan dan perkembangan akar serta kemampuan akar tanaman dalam menyerap unsure hara. Perkembangan system perakaran yang baik sangat menentukan pertumbuhan vegetatif tanaman yang pada akhirnya menentukan pula fase reproduktif dan hasil tanaman. Pertumbuhan vegetatif yang baik akan menunjang fase generatif.

Uji BNJ menunjukkan bahwa pemberian $2,5 \mathrm{~kg}$ bokashi sekam padi menghasilkan berat tongkol kotor dan berat tongkol kupasan paling berat, serta persentase panjang tongkol kosong terhadap tongkol isi terendah. Hal ini diduga pada dosis $2,5 \mathrm{~kg}$ bokashi sekam padi per $\mathrm{m}^{2}$ atau setara dengan 25 ton per hektar cukup baik dalam memperbaiki sifat-sifat tanah. Menurut Hakim dkk (1986), pemberian bahan organik pada tanah akan membuat pori tanah yang lebih besar sehingga meningkatkan perkembangan akar dan kemampuan akar menyerap air dan unsur hara yang pada akhirnya dapat mempengaruhi pertumbuhan serta hasil tanaman.

Adanya perbedaan yang nyata antara perlakuan bokashi sekam padi dengan tanpa penggunaan bokashi, karena bokashi sekam padi pada umumnya

mengandung unsur hara kompleks (makro dan mikro) walaupun dalam jumlah sedikit, selain itu secara fisik bokashi dapat memperbaiki struktur dan stabilitas agregat tanah, meningkatkan penyerapan dan daya simpan air, sehingga aktivitas mikroba tanah dapat berlangsung dengan tujuan mendukung dekomposisi bahan organik menjadi unsur hara yang tersedia bagi tanaman. Penggunaan bokashi juga dapat meningkatkan penyerapan nitrogen yang sangat berguna dalam proses fotosintesis. Proses fotosintesis berjalan dengan lancar maka karbohidrat yang dihasilkan akan lebih banyak, selain untuk pertumbuhan tanaman, hasil fotosintesis disimpan dalam bentuk tongkol jagung manis.

\section{KESIMPULAN DAN SARAN}

Bokashi sekam padi yang diberikan pada tanah PMK berpengaruh terhadap hasil tanaman jagung manis. Pemberian bokashi sekam padi sebanyak 2,5 $\mathrm{kg}$ per $\mathrm{m}^{2}$ atau setara dengan 25 ton per hektar memberikan hasil jagung manis tertinggi yang ditandai dengan rerata berat tongkol kotor 201 gram per tanaman, rerata berat tongkol kupasan 
184,25 gram, dan persentase panjang

tongkol kosong terhadap tongkol isi

$25,21 \%$.

\section{DAFTAR PUSTAKA}

Badan Pusat Statistik Kalimantan Barat. 2015. Kabupaten Sintang Dalam Angka. Pontianak: Badan Pusat Statistik.

Dinas Pertanian Kabupaten Jombang. 2010. Bokashi. Dinas Pertanian Kabupaten Jombang.

Hakim, N. Nyakpa, M.Y., Lubis, A.M., Nugroho, S.G., Saul, M.R., Diha, M.A., Hong, G.B., H.H. 1986. Dasar-Dasar Ilmu Tanah. Universitas Lampung. Lampung

Rismunandar, 2002. Budidaya Jagung. Jakarta: Penebar Swadaya.

Rukmana, R. 2013. Budidaya Jagung Hibrida. Yogyakarta: Kanisius.

Taufik, A. Mengenal Bahan Organik Lebih Jauh. Jakarta: Penebar Swadaya.

Yusuf, T. 2002. Bokashi. Jakarta: Penebar Swadaya.

Pengaruh Bokashi Sekam Padi Terhadap Hasil Tanaman Jagung Manis (Zea mays, L Sacharata) Pada Tanah Ultisol 
